\title{
Organizational and collaborative knowledge management: a Virtual HRD model based on Web2.0
}

\author{
Musadaq Hanandi* \\ Department of management engineering, University of Rome \\ "Tor Vergata", \\ Rome - Italy \\ Musadaq.hanandi@uniroma2.it
}

\begin{abstract}
Knowledge development and utilization can be facilitated by human resource practices. At the organizational level, the competitive advantage depends upon the firm utilization of existing knowledge and its ability to generate new knowledge more efficiently. At the individual level, increased delegation of responsibility and freedom of creativity may better allow the discovery and utilization of local and dispersed knowledge in the organization.
\end{abstract}

This paper aims at introducing an innovative organizational model to support enterprises, international companies, and governments, in developing their human resource, through the virtual human resource, as a tool for knowledge capturing and sharing inside the organization.

The VHRD organizational model allows different actors (top Management, employees, and external experts) to interact and participate in the learning process, by providing non-threatening self-evaluation and individualized feedback. In this way, the model, which is based on possible patterns and rules from existing learning systems, Web 2.0 and a homogeneous set of integrated systems and technologies, can be of support to the enterprise human resource department.

In addition to this, the paper presents an evaluation method to assess the knowledge management results inside the organisation, by connecting the financial impacts with the strategy map.

Keywords - Virtual Human Resource Development, Knowledge Management, Human Resource Management, Web2.0, Organizational model.

\section{INTRODUCTION}

Knowledge development and utilization can be facilitated by human resource practices ([1], [2], [3]). While the competitive advantage depends upon the firm utilization of the codified knowledge and its ability to generate and create new knowledge more efficiently ([1], [4], [5]), According to reference [6], the process of managing knowledge creation, integration and utilization inside the enterprise is linked to Human Resource Management (HRM) as a main coordination mechanism of these actions. Furthermore, the human resource is considered as crucially important in creating sustainable competitive advantage of organizations and enterprises ([7], [8]). Human resource practices and initiatives contribute to the firm's ability in utilizing their codified and existing knowledge to generate new knowledge ([9], [6]), adding to the firm a new competitive advantage ([10], [11]).

\author{
Michele Grimaldi \\ Department of Mechanics, Structures, Environment and \\ Territory, University of Cassino (Italy) \\ Cassino (FR) - Italy \\ M.grimaldi@unicas.it
}

According to the Resource Based View (RBV), the enterprises are able to create competitive advantage by means of developing and deploying their human resource in a way that adds unique value difficult to be imitated by the competitors. At the individual level, increased delegation of responsibility and freedom of creativity may better allow the discovery and utilization of local and dispersed knowledge in the organization, as well as expanding the depth and breadth of employee knowledge by promoting the process of knowledge creation and utilization through the individual learning practices such as" know how" or learning by doing [6].

Furthermore, the interpersonal cooperation and communication among the employees have been considered as one of the factors that likely utilizes knowledge diffusion and allows the employees to bond knowledge that is flying separately or dispersed across function, and creating new knowledge combination enhancing solving creative problems ([12], [13]). Continuously, the knowledge base of the firm reorganized by the interpersonal cooperation and communication between the employees, practices and communication managed and carried out by the HRM.

During the past years, many researchers introduced the Virtual Human Resource Management (VHRM) / and e- eHRM in different ways. These patterns can be considered as an application of information technology for both networking and supporting at least two individuals or collective actors in their shared performing of HR activities [14]. Accordingly to reference [15], the VHRM is characterized as a kind of network structure based on partnership, using information technology as carriers, to help organizations to access, develop and utilize the human capital.

During the past decades, the physical assets used to be considered as critical factor in determining the enterprise value and market's position, while on the current time this value is measured by their intellectual assets such as patents, technologies, ideas, and designs. Moreover, the main goal of the intangible asset management is utilizing tools and indicators to increase earnings within the business enterprise through managing knowledge [16].

But what challenges the enterprise is facing today are in codifying, sharing and applying knowledge inside their business environment in way they can benefit from the discoveries of others. Since firm's intangible asset development is strictly related to its competitive strategy and the adopted strategy reflects management's decision on how to respond to external reality ([17], [18]), managerial perception 
should shape knowledge resources and value of intangible assets to the organization [19].

This paper aims at introducing an innovative organizational model to support enterprises, international companies, and governments in developing their human resource through the VHRD, as a tool for knowledge capturing and sharing inside the enterprise for the purpose of the HRD (Experience, competences and production of new knowledge). In addition to this, the paper presents an evaluation method to assess the knowledge management results inside the organisation, by connecting the financial impacts with the strategy map.

The purpose of the proposed organizational model is to allow the different actors (top Management, employees, external experts) to progressively interact and participate in the learning process, by providing non-threatening self-evaluation and by defining individualized feedback to the learners and efficient tracking and supervision tools to the Human resource management.

\section{FROM KMS TOWARDS COLLABORATIVE KM}

In the last years, knowledge management has become one of the most considerable topics both in literature and in practice. Knowledge has assumed the role of strategic resource in companies searching for the competitive advantage ([1], [30], [31], [32], [17], [17]). Also according to Reference [26], knowledge is information possessed in the mind of individuals: it is personalized information (which may or may not be new, unique, useful, or accurate) related to facts, procedures, concepts, interpretations, ideas, observations, and/or judgments.

Today, companies need to manage this knowledge efficiently in order to succeed. In particular, they need to develop precise plans and to provide managerial guidelines, in order to make the available knowledge proper of the organization. As matters of fact, their success is strictly connected with the integration of tangible and intangible resources, organizational functions, core processes and technologies. Furthermore, the IT literature contributed greatly to the field of knowledge management, there is much more for knowledge management than just technology alone; knowledge management is a business process [26], the spread of information and communication technology has increased the ability of the firms to store, share and generate knowledge, accelerating the emergence of a new economic, organizational and technological context, named as "knowledge-based economy" [33], and in order to achieve a competitive position, it is very relevant to understand how the value creation processes and the business goals can be realized and combined ([30], [34], [35], [36]), but to identify that the pure availability of innovative technology not always involves an effective knowledge management.

According to [20], the information technology applications enable the firm to have a simple selection and internalization process only after having defined and codified the roles and the interpretative procedures. It appears that there is no direct correlation between information technology investments and knowledge management performance: business policies and practices are rather enabled by the strategic integration of information technology tools, business processes and intellectual, human and social capital ([21], [22], [23]).

Every organization has resources that are altered into capabilities such as the know-how that can be considered as tacit knowledge. Knowledge management has a purpose to create, collect and convert individual knowledge into an organizational one [24]. Nonaka presented also a dynamic theory of knowledge management that suggests that both explicit and tacit knowledge interact to generate process of organizational knowledge creation [25].

Organizational knowledge can be traced back to the beginnings of organizations where methods of scientific management and other succeeding management schools have implicit reference to current knowledge management practices. This is because organizations always have the need to deal with their internal or external experiences related to knowledge such as the patents or inventions [26]. However, it was in the mid or late 1980s that knowledge management emerged as an independent concept. This was a direct result of knowledge being an important source of competitive advantage for organizations [27]. Hereafter, two of the most relevant definitions of knowledge management found in literature are proposed. Firstly, it is the process of continually managing all kinds of knowledge to meet existing and emerging needs, to identify and exploit existing and acquired knowledge assets and to develop new opportunities [28]. Secondly, it is the effort to make the knowledge of an organization available to those within the organization who need it, where they need it, when they need it, and in the form in which they need it in order to increase human and organizational performance [29].

\section{A. Virtual Human Resource Development}

Considering the evolution from Human Resource Management (HRM) towards Human Resource Development (HRD), several and widely published definitions consider HRM as the major management activity. HRD usually includes a wider range of activities to develop personnel inside organizations, such as career development, training and development as well as the organization development [37]. Besides, at one hand the changes in definitions of HRM have not been significant, at the other; some definitions of HRD have made an important conceptual shift away from the process of training or organization development towards a focus on outcomes in terms of HRD's impact on people, Organizations, community, nation.

HRD is a major constituent of any civilization, and the more advanced it is the more thriving and prosperous a nation is. As with any other phenomena or ideology with crucial importance, it has been evolved from very intuitive to very complicated and advanced nowadays.

Today the world is experiencing and focusing on the web learning and the knowledge sharing phenomenon which has had major attention globally from governments and even worldwide institutions. Web Learning relies and is based upon technology and electronic means. This gave the rise to what is known as virtual education or Virtual Human Resource Development, which is the education and development training conducted online as opposed to the time and space bound traditional human resource development, in the age of 
obscurity, chaos, and change; the world is obscure as reality is not known, chaotic because the outcomes are never certain, and is changing as what can be true and right today would be completely the opposite tomorrow.

During the past years, many researchers introduced the Virtual Human Resource Management (VHRM) in different patterns where it is considered as an application of information technology for both networking and supporting at least two individuals or collective actors in their shared performing of HR activities [14]. According to reference [38], the Virtual HRM is characterized as a kind of network structure based on partnership, using information technology as carriers, to help organizations to access, develop and utilize the human capital.

According to reference [39], the Virtual HRM was introduced as "A process for developing and/or unleashing human expertise through training and development (T\&D) and organization development by utilizing a technology-enabled environment for the purpose of improving performance".

\section{A. The Role of KMS in HRD}

The KMS as an IT-based system was developed to support and enhance the organizational processes of knowledge creation, storage/retrieval, transfer and application [40]. With the growing attention of the KM importance in organizations, many of this start developing KMS that offer various benefits to facilitate KM activities [41], but [42], recommend that during the development of KMS, the organization should pay attention to various issues and challenges related to using IT to support KM.

Most of the traditional KMSs merely focus on capturing the enterprise's knowledge, storing and organizing it in the enterprise database. However, the purpose of the KMSs was not only to make information available, but also to make sure it will be shared and leveraged in enterprise context and between the users. Therefore, focusing only on the half of this equation does not add any advantage for human capital development. And the result will be that the KMS act like a cyberspace; full with immense amount of information and data, but still not yet leveraged, the VHRD model could be considered as the new generation of the KMSs or at least more mature.

In connection to this, the results of an online survey released by Accenture consulting firm in 2007 contain a survey of more than 1,000 middle managers of large companies in the U.S \& U.K [43]. These results uncover the way they gather, use and analyze information inside their organizations, and found that managers spend up to 2 hours a day looking for information, and more than $50 \%$ of what they found has no value to them. Furthermore, nearly three out of five respondents $(59 \%)$ said that, because of their company's poor information distribution, they lack access to critical information.
Moreover, various studies show that less than $20 \%$ of the knowledge inside enterprises is captured and in the same time less than $20 \%$ of that is retrieved in solving future problems and situations the enterprise faced [45].

Most of the traditional KMSs usually focus on capturing knowledge inside the enterprise and brushing off the importance of sharing this knowledge, and its affect on enterprise productivity and competitive advantage for both employees and enterprise.

\section{THE VHRD MODEL}

The VHRD model presents a new approach of utilizing the captured knowledge and information inside the enterprise environment (top management, external expertise, knowledge worker, workforce), and leveraging this knowledge to a dynamic $\mathrm{T} \& \mathrm{D}$ e-content for developing and enhancing the human capital competitive advantage.

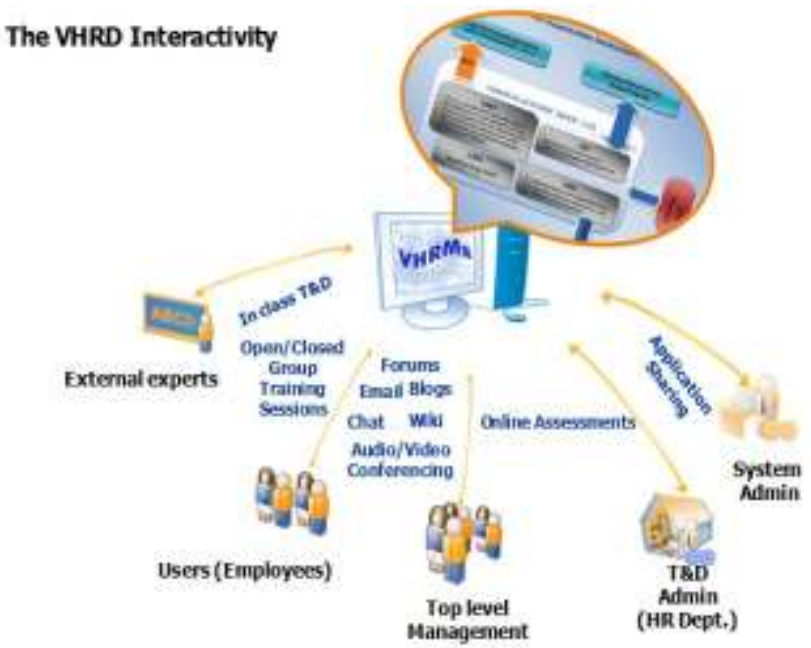

Figure 1. The interaction between the model users within the organisation environment

This model focuses on rendering the human capital with the skills needed and driving their performance to face any future situation and solve it, by capturing the knowledge object during the interaction activities between the users and reuse it in producing a dynamic e-content for the training and development purpose and in the same adding value for the enterprise competitive advantage; fig. 1 and fig. 2 illustrate the interaction between the users.

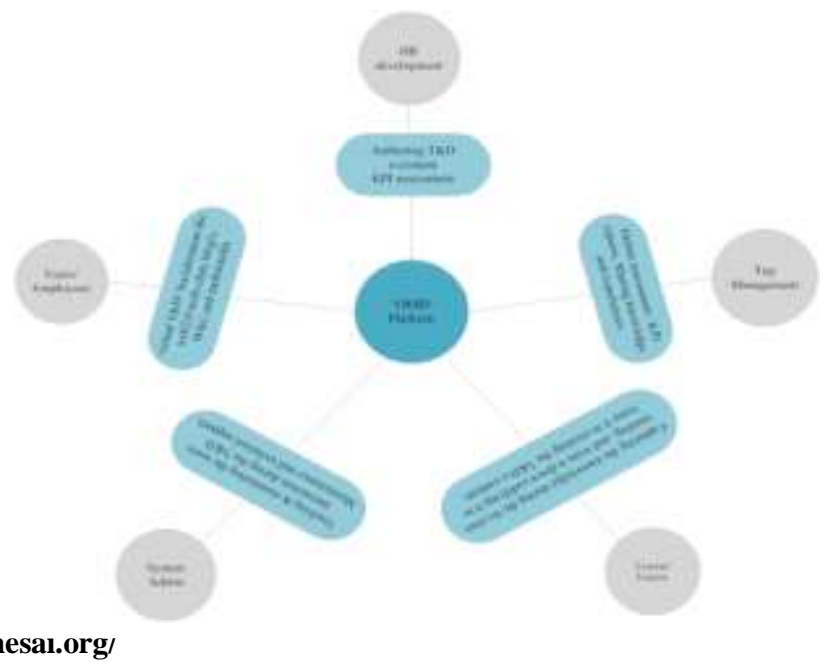


Figure 2. The interaction process actors and activities

As stated in the fig. 2 the VHRD counts on a number of actors and activities users the interaction process as it is described below in (Table I)

TABLE I USER'S INTERACTION PROCESS IN VHRD MODEL

\begin{tabular}{|c|l|}
\hline Actor & \multicolumn{1}{|c|}{ Activity Description } \\
\hline $\begin{array}{c}\text { Human } \\
\text { Resource } \\
\text { Development }\end{array}$ & $\begin{array}{l}\text { Authoring the T\&D e-content for the training courses, } \\
\text { updating it with the new captured knowledge to } \\
\text { enhance the user's competences, monitoring the user } \\
\text { progress, KPI assessment, and selecting the right T\&D } \\
\text { material according to the users and enterprise needs. }\end{array}$ \\
\hline $\begin{array}{c}\text { Top } \\
\text { Management }\end{array}$ & $\begin{array}{l}\text { Online assessment / KPI reports, Sharing knowledge } \\
\text { and experiences. }\end{array}$ \\
\hline External Experts & $\begin{array}{l}\text { Capturing the knowledge during the In-class training, } \\
\text { and write it down codifying it to reuse it in creating the } \\
\text { T\&D e-content. }\end{array}$ \\
\hline $\begin{array}{c}\text { System } \\
\text { Administrator }\end{array}$ & $\begin{array}{l}\text { Tracking the user interactivity during the virtual T\&D } \\
\text { period, maintenance and upgrade and updating the } \\
\text { used systems and any further technical requirements. }\end{array}$ \\
\hline $\begin{array}{c}\text { Users / } \\
\text { Employees }\end{array}$ & $\begin{array}{l}\text { Virtual T\&D courses, Social network tools (Chat, } \\
\text { multimedia communication), Web2.0 tools (Wiki, } \\
\text { Blogs), to share ideas, information, experience, } \\
\text { knowledge, Case failure/success. }\end{array}$ \\
\hline
\end{tabular}

\section{B. The conceptual model}

VHRD model utilizes the knowledge captured from the interaction between the enterprise members and the codified knowledge inside the enterprise environment context. Furthermore, leverage this knowledge in a dynamic training and development e-content to enhance the human capital skills, competence, knowledge, experiences and improve their performance.

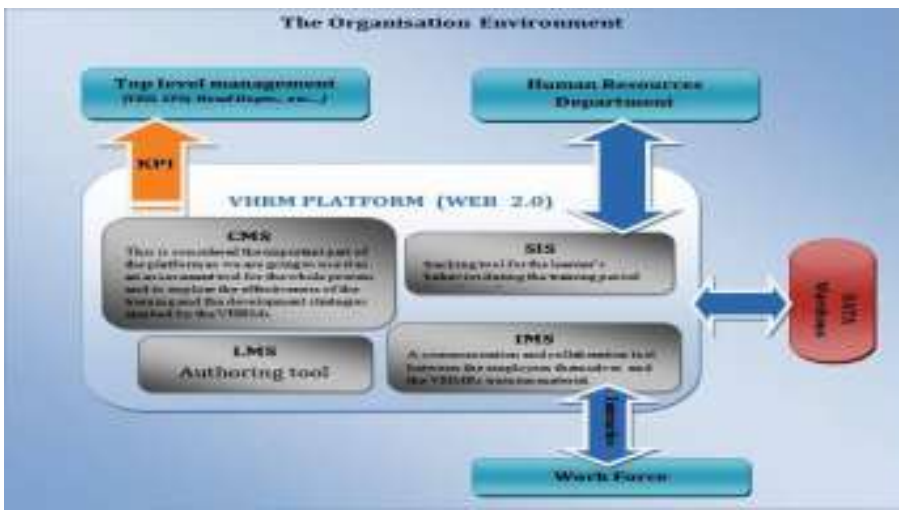

Figure 3. The VHRD conceptual model components

The proposed model (Fig. 3) facilitates these activities through the web 2.0 tools, information management system (IMS) and learning management system (LMS), where together are considered the backbone of the interaction activities, allowing the enterprise members to interact extensively in a high secure and trusted environment, and facilitate the freely information flows and intensive hands-on experience to induce knowledge accumulation in the data warehouse, where knowledge will be codified, documented and indexed or in another word "took stock" that mean it's ready to be accessed and shared inside the enterprise environment or as its proposed in this model to share it the VHRD model in order to develop and train the internal workforce of the enterprise.

The development of the dynamic T\&D e-content counts on the accumulated knowledge in the data warehouse, after it has been created, shared, and captured during the interaction activities between the employees inside the enterprise, thanks to the web 2.0 technology.

The authoring process for different $\mathrm{T} \& \mathrm{D}$ dynamic objects will count on the integrated LMS in the model and human resource department of the enterprise, which will have another role of following and tracking the user's activities during the interaction activities, through the student Information system (SIS) which will work as a tracking and user feedback tool.

The competency management system (CMS) play the role of the intelligent self-evaluation and grade reporting system for the competencies that have been earned during the T\&D course, and steering of competence development \& direction, besides, the management of unstructured competence (tacit knowledge), moreover the CMS will provide the VHRD administrators with the competencies earned by the employees and how this influence their work, competences and competitive advantage among the growing need for high and qualified work force, which directly affect the enterprise competitive advantage among their competitors.

The VHRD model consists of different learning technologies with a different relationship (Table II) to serve and support the international enterprises with the process of sharing and capturing dynamic knowledge objects that could be created through a continuous dialogue between tacit and explicit knowledge, to be utilized for the HRD purpose and creating a competitive advantage for both the organization and employees. Besides, the contributing to the development of empirical research in the domain of virtual human resource development aimed at clarifying the relationship between virtual human resource development and knowledge management orientation. The paper contributes towards a better understanding of the degree of adoption of such a model in the enterprises, international companies, and governments, paving the way for future comparative studies which might take other sectors (health, education) into consideration. 
TABLE II THE VHRD MODEL STAKEHOLDER RELATIONSHIPS

\begin{tabular}{|c|c|c|c|}
\hline Actor Name & Abb. & Role & $\begin{array}{l}\text { Relationship } \\
\text { with }\end{array}$ \\
\hline $\begin{array}{l}\text { Learning } \\
\text { Management System }\end{array}$ & LMS & $\begin{array}{l}\text { T\&D e-content } \\
\text { authoring role }\end{array}$ & HRM, DW, U \\
\hline $\begin{array}{l}\text { Information } \\
\text { management system }\end{array}$ & IMS & $\begin{array}{l}\text { Communication and } \\
\text { collaboration Role }\end{array}$ & $\begin{array}{l}\text { U,LMS, SIS, } \\
\text { Web2.0, CMS }\end{array}$ \\
\hline $\begin{array}{l}\text { Student Information } \\
\text { system }\end{array}$ & SIS & $\begin{array}{l}\text { Dynamic user feedback } \\
\text { tool }\end{array}$ & HRM, U, TM \\
\hline Web 2.0 & Web.2.0 & $\begin{array}{l}\text { Dynamic environment } \\
\text { for interaction between } \\
\text { the user through web2.0 } \\
\text { tools }\end{array}$ & $\begin{array}{l}\text { IMS, LMS, U, } \\
\text { DW }\end{array}$ \\
\hline $\begin{array}{l}\text { Competency } \\
\text { Management System }\end{array}$ & CMS & $\begin{array}{l}\text { Intelligent self- } \\
\text { evaluation for the } \\
\text { competency earned from } \\
\text { the proposed T\&D e- } \\
\text { content. }\end{array}$ & HRM, TM \\
\hline $\begin{array}{l}\text { Enterprise } \\
\text { Environment }\end{array}$ & $\mathrm{EE}$ & $\begin{array}{l}\text { Where K create, share, } \\
\text { capture and retrieved as } \\
\text { a T\&D e-content }\end{array}$ & HRM, DW \\
\hline Data Ware house & DW & $\begin{array}{l}\text { Codifying and } \\
\text { accumulating the } \\
\text { captured knowledge for } \\
\text { T\&D purpose. }\end{array}$ & HRM, U \\
\hline $\begin{array}{l}\text { Human Resource } \\
\text { Management }\end{array}$ & HRM & $\begin{array}{l}\text { The VHRD model } \\
\text { administrative for the e- } \\
\text { content development for } \\
\text { the users }\end{array}$ & $\begin{array}{l}\text { LMS, U, DW, } \\
\text { TM }\end{array}$ \\
\hline $\begin{array}{l}\text { Top } \\
\text { management/Stock } \\
\text { holders }\end{array}$ & TM & $\begin{array}{l}\text { TM affect or be affected } \\
\text { by the attainment of } \\
\text { organizational } \\
\text { model.(earning retunes, } \\
\text { profits, competitive } \\
\text { advantage) }\end{array}$ & $\begin{array}{l}\text { KPI, CMS, } \\
\text { WEB2.0 }\end{array}$ \\
\hline Users / Employees & $\mathrm{U}$ & $\begin{array}{l}\text { End User of the VHRD } \\
\text { Model }\end{array}$ & VHRD Model \\
\hline $\begin{array}{l}\text { Key Performance } \\
\text { Indictors }\end{array}$ & KPI & $\begin{array}{l}\text { Measurement tool for } \\
\text { the }\end{array}$ & TM, HRM \\
\hline $\begin{array}{l}\text { Virtual Human } \\
\text { Resource } \\
\text { Development }\end{array}$ & VHRD & $\begin{array}{l}\text { Human resource } \\
\text { development and } \\
\text { training }\end{array}$ & All \\
\hline
\end{tabular}

\section{Practical implementations}

The model should serve and support the enterprise in processing the tacit knowledge inside their environment and utilizing the captured data, in creating a dynamic T\&D econtent to enhance the employees experiences, competency, innovation, and at the same time supporting the enterprises by providing them with the proper technology model for knowledge utilization and processing to get the ultimate benefit of the codified and accumulated knowledge in their database.

However, enterprises have different process and structure drawing by their own unique identity, therefore, developing and implementing the VHRD model inside these enterprises was drawn as follows:
Change management process as a first step, through the attempt of changing and creating new values, organizational culture, beliefs and behaviors inside the enterprise for both management and employees.

The business processes reengineering inside the enterprise environment and differs from business to another focusing on the information flow, data management and the needed qualified people in all the enterprise levels.

Technology readiness aspect which is considers the existence of the relevant technology solutions and tools, as well as the availability of specific competencies and skills of the people using this technology. Usually, this is determined by assessing existing IT infrastructure and strategies.

Knowledge and Communication aspects are necessary to the transition process. These refer to the communication models and the way that knowledge is shared and exchanged in the enterprise's platforms and technology.

Furthermore, the dimensions of this model could help an enterprise VHRD project team to check whether all relevant factors are covered within the implementation and changing processes, and regardless of the long-term perspective of most change management and business reprocess engineering programmers, the short-term improvements have to be achieved in order to preserve enough activity to continue going for further growth and commitment on all organizational levels.

\section{Comparison with the traditional KMS}

Before introducing the VHRD model business impact, the paper goes in a comparison with the traditional KMS. Table III summarizes this comparison.

TABLE III VHRD MODEL COMPARISON AMONG TRADITIONAL KMS

\begin{tabular}{|l|l|l|}
\hline Compression & \multicolumn{1}{|c|}{ Traditional KMS } & \multicolumn{1}{c|}{ VHRD model } \\
\hline Connectivity & Online/intranet & Online/ intranet \\
\hline Content & $\begin{array}{l}\text { Out-dated, irrelevant, } \\
\text { ill-structured }\end{array}$ & $\begin{array}{l}\text { Utilized according to the } \\
\text { business requirement/ } \\
\text { employees need/ updated } \\
\text { with the new knowledge } \\
\text { captured }\end{array}$ \\
\hline Community & $\begin{array}{l}\text { Management not } \\
\text { involved/ organization } \\
\text { internal environment }\end{array}$ & $\begin{array}{l}\text { Management involved / } \\
\text { external expertise } \\
\text { /organization } \\
\text { environment }\end{array}$ \\
\hline Culture & $\begin{array}{l}\text { Contract Sharing } \\
\text { Knowledge (forced } \\
\text { without motivation) }\end{array}$ & $\begin{array}{l}\text { Sharing for development } \\
\text { and earning new } \\
\text { experiences/ } \\
\text { Management } \\
\text { commitment through } \\
\text { their participation }\end{array}$ \\
\hline Capacity & $\begin{array}{l}\text { Online interaction } \\
\text { Business } \\
\text { strategy }\end{array}$ & $\begin{array}{l}\text { In-class } \\
\text { interaction/online } \\
\text { interaction /external } \\
\text { expertise }\end{array}$ \\
\hline $\begin{array}{l}\text { Traditional KMS taken } \\
\text { as a short project and non } \\
\text { long term project/ } \\
\text { Knalignment between the } \\
\text { the strategy goals. }\end{array}$ & $\begin{array}{l}\text { VHRD aligning between } \\
\text { the Knowledge managed } \\
\text { and the strategy goals of } \\
\text { the organization. }\end{array}$ \\
\hline
\end{tabular}




\begin{tabular}{|l|l|l|}
\hline $\begin{array}{l}\text { Business } \\
\text { Impact }\end{array}$ & $\begin{array}{l}\text { Deficulyies in defining } \\
\text { the business impact. }\end{array}$ & $\begin{array}{l}\text { Knowledge evaluated } \\
\text { according to } \\
\text { performance. } \\
\text { Measurement of ROI and } \\
\text { the achievements of the } \\
\text { employee's performance. }\end{array}$ \\
\hline
\end{tabular}

The comparison which is held based on Connectivity, Content, Community, Culture, Capacity, Business strategy, Business Impact. These six criteria show us the difference among the traditional KMS and the VRHD model, and why the VHRD model could be considered as the next KMS generation.

Therefore, the paper considers the VHRD model as a candidate to replace the traditional KMS, as a innovative technological solution for the human resource development and grapping the benefits to the business with high financial impact.

\section{EVALUATION OF THE BENEFITS OF THE MODEL}

Measuring direct business impact is the most powerful way to demonstrate the added value of VHRD model on enterprise performance and the human capital competencies.

The necessity of evaluating the benefits, for tangible and intangible value added, has led to the proposition of an approach based on the Balanced Scorecard (BSC) method.

The BSC offers an architecture to evaluate how intangible assets help create value in terms of financial income. The BSC emphasizes the importance of non-financial indicators, by proposing a hierarchy among the four axes: customer satisfaction, internal processes, organizational learning, and value for shareholders. In particular, the first three axes are merely the means to achieve financial targets, which is the fourth axis.

Thus human skills (in line of organizational learning) improve productivity and quality of services (internal processes), which in turn contribute to customer satisfaction and ultimately serve for financial objectives of the company.

For this reason, the Balanced Scorecard can be considered as a very result-oriented economic, even if financial aspect cannot be considered as a tool for evaluating the overall performance.

The BSC could be considered as an important contribution to $\mathrm{KM}$ evaluation and measurements, while the traditional financial indictors focused on measuring the tangible assets. As a consequence, the BSC offers architecture model to evaluate how intangible assets help to create value in terms of financial income.

A new requirement of knowledge management today is the ability to monitor and evaluate, in addition to financial results, all the factors involved in the process of value creation. The best answer appears to be the establishment of an effective reporting system dedicated to performance management that is easily accessible, legible and safe. The BSC creates a strategic management system of this kind means "to improve performance to optimize the business", by identifying the improvement areas in line with the broad holding link between strategic planning and operational implementation of the business strategy.
Fig. 4 illustrates how the BSC system supports the enterprises to focus on the performance metrics, by means of balancing financial objectives with customer, internal business process and learning (innovation) after the implementation of the VHRD organizational model. This process will optimize the human capital skills and competences in the mean of organizational learning, which should develop the employees (ideas, skills, experience, innovation, competences) and improve their productivity and quality of services with the mean of internal processes. Besides, the quality and the improvement of the customer relationship management in mean of stakeholder satisfaction and ROI.

Moreover, this process is considered as a continuous knowledge life cycle, where the improvement, learning and human capital development are keep running. The internal processes will keep improving as well as financial objectives will keep growing.

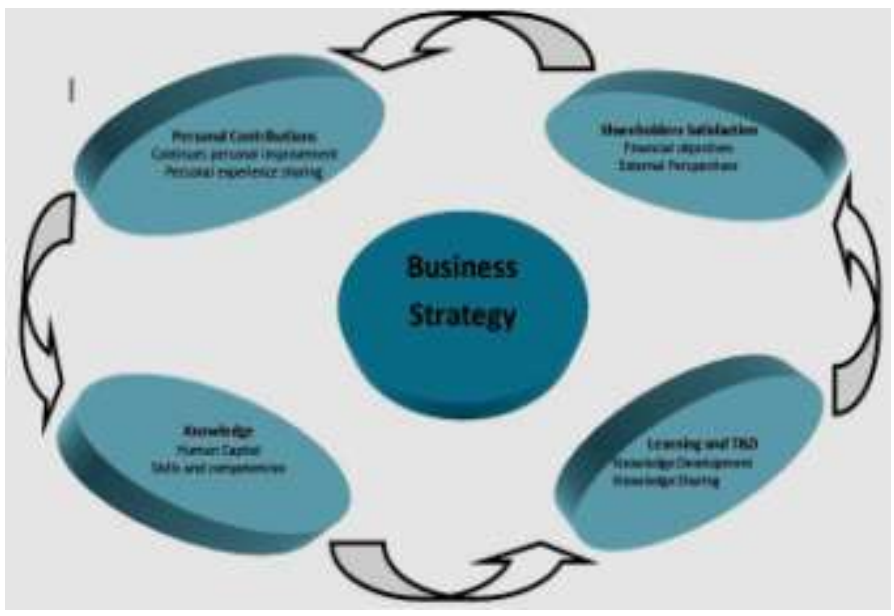

Figure 4. The VHRD performance balanced scorecard cycle.

The five linked perspectives of performance define the VHRD model performance measurement metrics, by identifying the questions which tackle the following subjects:

- Strategy: what strategies do the firms have to put in place in order to satisfy the requirements and the needs of the key stakeholders e.g. change management strategy?

- Shareholder satisfaction: who are the firm's key shareholders and what are their requirements and needs from the VHRD model?

- Knowledge: what critical knowledge do the firms need to operate and enhance their processes, their employees, experiences and knowledge process?

- $\quad$ Learning and T\&D: what kind of T\&D do firms need to operate and enhance their processes and productivity?

- Personal contribution: what contributions do firms require from their employees to maintain and develop their knowledge?

Today there are several KM evaluation tools that could be utilized to evaluate and assess the organization knowledge flow 
value. To realize benefits counts essentially on the implementation of VHRD systems, where practitioners can learn extensively from each other and develop their competences and skills.

Besides, the influence image that comes through VHRD is not simply a technological solution to share knowledge among the organization members, but also a system which connects employees, managers, and involved processes.

Moreover, to state this point, many of the KM groundbreakers, who have seen their organizations attain significant benefits, did not have to disclose ROI in financial terms. There are several leaders who have a clear vision and understanding about the non-rational contribution of $\mathrm{KM}$ to their business processes and human capital development, without having a proper justification in terms of ROI. In addition to this, many managers face problems in calculating the added value to their financial statement, deriving from managing their organization knowledge and utilizing and implementing different tools and technology. Thus the following steps draw a road map to support the managers in calculating the financial impacts of such VHRD model or in general any KMSs.

\section{1) Identify the model goals}

To implement the VHRD model enterprise should identify gaps between outcomes that expect (performance) and what is actually happening related to employee job performance. Thus identified specific gaps and looking to fill them by the virtual T\&D.

Moreover, this may include improved productivity/quality, reduced scrap/waste, reduction in accidents or injuries, improved customer satisfaction, reduced customer complaints or some other aspect of job performance, which increased skills and abilities gained through training should positively impact.

Soft skill training such as supervisory or communication training can be more difficult to measure.

\section{2) Develop model evaluation criteria}

Identifying specific criteria to measure the success of the training held through the VHRD model, these criteria may include quality control reports, scrap reports, production statistics or any other measurable elements.

Establishing a baseline level by determining the current level of performance against each measuring criteria before the model implementation and training commences, so the top management will have a clear understanding of the effect of the VHRD model has on performance. Without specific and measurable criteria, it is virtually impossible to measure the impact of VHRD model effects.

\section{3) Collect feedback during \& after the model implementation}

It's important to seek feedback from the users regarding their training and interaction experience. The feedback should include satisfaction with the model and its features as well as the training and specific action plans being developed based on the learning (i.e. how are they going to apply the training to their job), these action plans should assist in measuring the impact of the T\&D.

\section{4) Collect Data re: Impact of model on evaluation criteria}

Based on the criteria identified in the second step, monitor and track performance against the baseline data. The positive change in these elements represents the real impact of the T\&D programs.

While there may be some other elements the management would like to consider, such as the users being happier employees, if those elements not translated into a measurable improvement against the baseline of the evaluation criteria, there is no real way to factor it into the ROI calculation.

\section{5) Translate Impact Data into Financial Benefits of VHRD T\&D Program}

Based on the data collected and the performance improvement against the baseline data, the real financial impact of the model T\&D can be calculated.

Using criteria such as improved productivity or reduced scrap/waste, the management will be able to calculate the actual financial value and benefits that the VHRD model is providing.

\section{6) Calculate the Model Costs}

The costs of running the VHRD should be fully loaded into this calculation.

Costs should include applicable items including the administrative and operational costs. And overhead costs for the organization can also be allocated to it.

The period for which the returns from the VHRD model calculated may vary, but as a general rule, it should not exceed one year from the completion of the model implementation.

\section{CONCLUSIONS}

Learning plays a critical role in our everyday lives. Education has evolved from very primitive to highly advanced and technologically based methods, this evolution is necessary and normal so as to adapt with the knowledge economy and its requirements and challenges nowadays. New words and concepts have evolved since the integration of technology in the learning field and the benefits can be sensed at all levels and at various degrees.

There is no doubt that knowledge management is entering a new phase of theoretical and practical development.

The presented VHRD model, as organizational approach based on Web 2.0 for collaborative KM, offers a coherent solution to this challenge. The VHRD model is built on a theoretical framework and on an integrated modeling method with organizations.

Also this basic framework has been enhanced with empirically validated and practically proven knowledge management element like the four core activities as well as criteria for analysis and design of a coherent knowledge management solution. 
Besides, knowledge management provides a kind of toolbox with several generic methods, instruments and tools to improve the handling of knowledge in daily routine.

Moreover, the technological opportunities to improve interaction and increase collaboration in enterprises are growing rapidly and the need for an organizational model that can utilize the human resource capabilities and knowledge worker inside the enterprises become highly demandable, there are many benefits of a well-designed knowledge collaboration system taking in our consideration the importance role that human resource play in knowledge creation, sharing and applying it, through utilizing this captured knowledge in a econtent object for T\&D purpose of the employees inside the enterprise environment, this also includes saving time, effort and cost to get the right knowledge usually expected of the traditional training and development courses.

\section{REFERENCES}

[1] Nonaka, I., Takeuchi H. (1995) The Knowledge Creating Company, Oxford University Press, New York.

[2] Leiponen, A., (2000), "Collaboration, Innovation, and Firm Performance - Increasing Returns from Knowledge Complementarities ?", Paper prepared for the Conference "Supermodularity and Innovation", UQAM, Montréal, June.

[3] Laursen, K. (2002), "The Importance of Sectoral Differences in the Application of Complementary HRMPractices for Innovation Performance", International Journal of Economics and Business, Vol. 9, pp. 139-156.

[4] OECD, (2000), Knowledge Management in the Learning Economy, Paris.

[5] Tidd, J., (2000), From Knowledge Management to Strategic Competencies, Series on Technology Management, Vol. 3, Imperial College Press, London.

[6] Laursen K., \& Mahnke, V. (2001). Knowledge strategies, firm types, and complementarity in human-resource practices. Journal of Management and Governance, 5, 1-27.

[7] Colbert, B. A. (2004). The complex resource based view: Implications for theory and practice in strategic human resource management. Academy of Management Review, 29, 341-358.

[8] Subramony, M., Krause, N., Norton, J., \& Burns, G. (2008). The Relationship Between Human Resource Investments and Organizational Performance: A Firm-Level Examination of Equilibrium Theory. Journal of Applied Psychology, 93, 778-788

[9] Lado, A. A., \& Wilson, M. C. (1994). Human Resource Systems and Sustained Competitive Advantage: A Competency Based Perspective. Academy of Management Review, 19, 699-727.

[10] Amit, R., \& Schoemaker, P. J. H. (1993). Strategic assets and organizational rent Strategic Management Journal, 14, 33-46.

[11] Barney, J. (1995). Looking inside for competitive advantage. Academy of Management Executive, 9, 49-61.

[12] Pini, P., and G. D. Santangelo (2005): "Innovation types and labour organizational practices: a comparison of foreign and domestic firms in the Reggio Emilia industrial districts," Economics of Innovation and New Technology,14(4), 251-276.

[13] Souitaris, V. (2002). Firm-specific competencies determining technological innovation: A survey in Greece. R\&D Management, 32, 61-77.

[14] Strohmeier, S. (2007). Research in e-HRM: Review and Implications, Human Resource Management Review, 17 (1), 19-37.

[15] Lepak, D.P., \& Snell, S.A. 1998. Virtual HR: Strategic human resource management in the 21st century. Human Resource Management Review, 8: 215-234.
[16] Sullivan, P. H. (1998). Value-Driven Intellectual Capital: How to Convert Intellectual Corporate Assets into Market Value. Brisbane: Wiley.

[17] Zack, M.H. (1999) Managing Codified Knowledge, Sloan Management Review, Summer 1999, 40:4, pp. 45-58.

[18] Zack, M.H. (1999) 'Developing a Knowledge Strategy', California Management Review, Vol. 41, No. 3, pp. 125-145.

[19] St Leon, M.V. (2002), Intellectual Capital: Managerial Perceptions of organizational knowledge resources, Journal of Intellectual Capital, Vol. 3, No. 2, pp. 149-166.

[20] Bloodgood, J.M., Salisbury, W.D. (2001) 'Understanding the influence of organizational change strategies on information technology and knowledge management strategies', Decision Support Systems, Vol. 31, pp. 55-69.

[21] Carayannis E.G., Alexander J. (1999) 'Winning by Co-Opeting in Strategic Government-University-Industry R\&D Partnerships: The Power of Complex, Dynamic Knowledge Networks', Journal of Technology Transfer, Vol. 24, pp.197-210.

[22] Carayannis, E. G. (1999) 'Fostering synergies between information technology and managerial and organizational cognition: the role of knowledge management', Technovation, Vol. 19, pp. 219-231.

[23] Malhotra, Y. (1998) 'Deciphering the knowledge management hype', Journal for Quality and Participation, Vol. 21, No. 4, pp. 5860 .

[24] Nonaka, I. (1998). The Knowledge-Creating Company. Harvard Business Review on Knowledge Management, Boston: Harvard Business School Press.

[25] Nonaka I., \& Konno, N. (1998) The Concept of Ba: Building a Foundation for Knowledge Creation. California Management Review, 40 (3), 40-54.

[26] Sarvary, M. (1999). Knowledge management and competition in the consulting industry. California Management Review, 41 (2), 95107.

[27] Wiig, Karl M. (1997), Integrating Intellectual Capital and Knowledge Management, Long Range Planning, Vol. 30, No. 3, June, pp. 399-405.

[28] Quintas,P., Lefrere, P., Jones, G. (1997), “Knowledge management: a strategic agenda", Journal of Long Range Planning, Vol. 30, No. 3; pp.385-91.

[29] Ives W, Torrey B. Gordon C (1998). "Knowledge management: anemerging discipline with a long history", J. Knowl. Manage. 1(4): 269-273.

[30] Davenport, T., Prusak, L. (1998) Working Knowledge: How organization manage what they know, Harvard Business School Press, Boston, MA.

[31] Skyrme D.J. (2000) 'Developing a Knowledge Strategy: From Management to Leadership', in Morey, D., Maubury, M. and Thuraisingham, B. (Eds.), Knowledge Management: Classic and Contemporary Works, MIT Press, MA.

[32] Tiwana A. (2000), The Knowledge Management Toolkit: Practical Techniques for Building a Knowledge Management System, Prentice-Hall PTR, NJ.

[33] Schwartz, P., Kelly, E., Boyer, N. (1999) 'The Emerging Global Knowledge Economy', OECD (Hg.): The Future of the Global Economy. Towards a Long Boom?, Paris.

[34] Anand, V., Manz, C. C., Glick, W. H. (1998) 'An organisational memory approach to information management', Academy of Management Review, Vol. 23, No. 4, pp. 796-809.

[35] Hansen, M. (1999) 'The Search-Transfer Problem: The Role of Weak Ties in Sharing Knowledge Across Organizational Subunits', Administrative Science Quarterly, Vol. 44, No.1, pp. 82-111.

[36] Hansen, M.T., Nohria, N., Tierney, T. (1999) 'What's your strategy for managing knowledge?', Harvard Business Review, pp.106-116. 
[37] McLean, G. N., \& McLean, L. (2001). If we can't define HRD in one country, how can we define it in an international context? Human Resource Development International, 4(3), 313-326.

[38] Lepak, D.P., Snell, S.A. (1998), "Virtual HR: strategic human resource management in the 21st century", Human Resource Management Review, Vol. 8 No.3, pp.215-34.

[39] McWhorter, Mancuso, \& Hurt. "Adult Learning in a Virtual Environment" 2008.

[40] Alavi, M. and D. E. Leidner (2001). "Review: Knowledge Management and Knowledge Management Systems: Conceptual Foundations and Research Issues.” MIS Quarterly 25(1):107-136.

[41] Alavi, M. and D. E. Leidner (1999). "Knowledge Management Systems: Issues, Challenges and Benefits." Communications of AIS 1: 1-37.

[42] Hahn, J. and Subramani, M.R. 2000.A Framework of Knowledge Management Systems: Issues and Challenges for Theory and Practice Proceedings of the 21st International Conference on Information systems, pp302-312.

[43] "Middle Managers Around the World Unsatisfied with Their Organizations", Accenture Survey Finds, Press Release, Accenture, January 09, 2007.

[44] Alavi, M. and A. Tiwana. (2002), 'Knowledge integration in virtual teams: The potential role of KMS', Journal of the American Society for Information Science and Technology, 53(12):1029-1037.

[45] Fruchter, R., Demian, P., 2002. CoMem: Designing an interaction experience for reuse of rich contextual knowledge from corporate knowledge. Artifical Intelligence for Engineering Design, Analysis and Manufacture 16, 127-147.

\section{AUTHORS PROFILE}

Michele Grimaldi received his first-class honor degree and a Master in Industrial Engineering. He received his doctorate in Industrial and Management Engineering from the University of Rome 'Tor Vergata'. He is a researcher at the faculty of Engineering of the University of Cassino (Italy). He teaches MBA and undergraduate courses on Economics of Industrial Systems and Knowledge Management. He has published papers in International Journals and Conference Proceedings. His current research field is focused on knowledge management strategies and metrics.

Musadaq Hanandi is a Ph.D. candidate in the School of Business engineering at the University of Rome "Tor Vergata". He holds a MS in e-Business Management from Salento University- ISUFI School. He has co-authored articles in Small Group Research. His primary research interests are in Knowledge Management and Virtual Human Resource Development 